\title{
Anatomy of the Male Reproductive Organ of Water Monitor Lizard, Varanus salvator bivittatus (Reptil: Varanidae)
}

\author{
Mahfud1,2*, Chairun Nisa'3 ${ }^{3}$ Adi Winarto ${ }^{3}$ \\ ${ }^{1}$ Study Program of Animal Anatomy and Development, Graduate School, Bogor Agricultural University \\ ${ }^{2}$ Biology Educational, Faculty of Teacher Training and Educational Sciences, University of Muhammadiyah \\ Kupang, Jl. KH. Ahmad Dahlan Walikota Kupang 82558 \\ ${ }^{3}$ Department of Anatomy, Physiology dan Pharmacology, Faculty of Veterinary Medicine, Bogor Agricultural \\ University, Jl. Agatis Kampus IPB Dramaga Bogor 16680 \\ *Corresponding author: mahfud.aph@gmail.com
}

Keywords: Varanus salvator bivittatus, hemipenes, propulsar muscles

\section{INTRODUCTION}

One of the majority species of Varanidae is Varanus salvator or which commonly known as water monitor lizards (water monitor) or Asian water monitor lizard. This species is the most widely spread out of the all varanids. In Indonesia, $V$. salvator are distributed in almost all islands, from Sumatra, Java, Sulawesi, Maluku and Flores. Subspecies V. s. bivittatus was found only in Java, Bali and South East Islands [1].

The information on reproductive biological aspects of the $V$. s. bivittatus, especially the male reproductive organs is limited. Therefore, the study was aim to explore the male reproductive organs system of $V$. s. bivittatus that focused on macroscopic evaluation.

\section{MATERIALS AND METHODS}

Two adult male lizards with $45.60 \mathrm{~cm}$ SVL from Bogor area were used in this study. The lizard were anesthetized and exanguinated to sacrifice and fixed in $4 \%$ paraformaldehyde through perfusion then followed by visceral observation and morphometric carefully measurement.

All the observation finding and collected data were analyzed descriptively and presented in the form of tables and figures. Morphometric data were tabulated in the form of the average (mean) \pm standard deviation (SD).

\section{RESULTS AND DISCUSSION}

The male reproductive organs of the $V$. s. bivittatus were generally similar to other vertebrates, which consists of testes, epididymis, deferent duct, and penis (specifically in reptiles are named hemipenes). All the identified organ were rise in a pair including its hemipenes. While their organ size are shown in Table1.

Both testes were situated in the dorsal wall of the coelom attached by mesorchium, precisely at the cranial region of kidney (Fig. 1). The testes have oval-shaped, pale white in color as well as turtle Phrynops geoffroanus [2]. The epididymis appear from cranial part of testes, pass through the ventral kidney toward the caudal end. The yellowish duct runs together with ureter and ended in cloaca. The epididymis was not formed head, body and tail as it showed in mammals. At the caudal end of kidneys, epididymis was connected to the deferent duct, which identified as a small, straight and short duct (Fig. 1B). As in other amniotic species, deferent duct functioned as gametes transportation, while in the reptiles which then flow through sulcus spermaticus at the hemipenes.

Hemipenes V. s. bivittatus was a pair of cylindrical organ (truncus) located at caudal cloaca in its own grove with separated exit pool. In the flaccid state, the head of the hemipenes located in the caudal part, while at the time of erection, hemipenes will come out of the lateral side of the cloaca, so that the location of the head moves to the cranial hemipenes. At the head hemipenes was found mucosa folds, it different to those in snakes, which covered by bumps (papillae) shaped like a thorn [3]. During erection state, sulcus spermaticus at the outer surface of hemipenes lining from head to the radix area. In the middle of the head hemipenes anthers like protrusion was found, which is similar to tendon in its consistency, white in colour, and composed of connective tissue. Within flaccid state, the protrusion goes down to the base of truncus hemipenes since it connected to 
retractor muscles of hemipenes that commonly known as muscle propulsar.

Table 1. The size the male reproductive organs of the V. s. bivittatus

\begin{tabular}{llcc}
\hline \multicolumn{1}{c}{ Organs } & \multicolumn{1}{c}{ Measure } & Right $(\mathrm{cm})$ & Left $(\mathrm{cm})$ \\
\hline Testes & Length & $3.15 \pm 0.59$ & $3.38 \pm 0.39$ \\
& Diameter & $1.24 \pm 0.18$ & $1.36 \pm 0.06$ \\
Epididymis & Length & $10.57 \pm 0.36$ & $10.33 \pm 0.16$ \\
& Diameter & $0.68 \pm 0.30$ & $0.68 \pm 0.30$ \\
Deferent duct & Length & $0.57 \pm 0.48$ & $0.35 \pm 0.30$ \\
& Diameter & $0.30 \pm 0.042$ & $0.30 \pm 0.02$ \\
& Length & $3.41 \pm 0.98$ & $3.52 \pm 1.11$ \\
& Diamater of head & $1.31 \pm 0.07$ & $1.33 \pm 0.10$ \\
& Diameter of body & $1.08 \pm 0.04$ & $1.08 \pm 0.04$ \\
& Diameter of radix & $0.80 \pm 0.10$ & $0.80 \pm 0.10$ \\
\hline
\end{tabular}

Notes: *hemipenes are measured in a state of erection

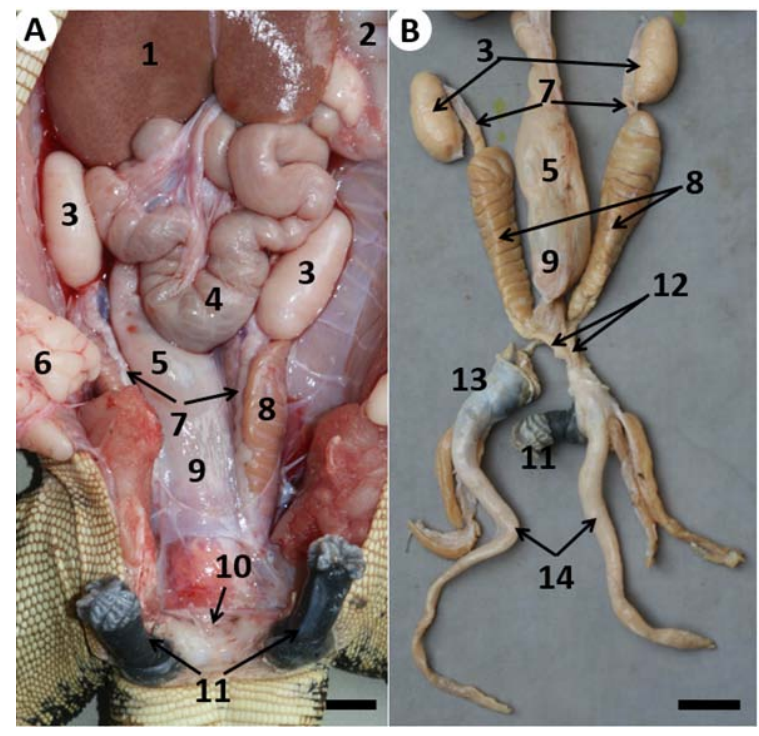

Figure 1. Male reproductive organs of the V. s. bivittatus (dorsal view). 1. Liver, 2. Stomach, 3. Testes, 4. Small intestine, 5. Large intestine, 6. Fat pad, 7. Epididymis, 8. Kidney, 9. Bladder, 10. Cloaca, 11. Hemipenes (erection state), 12. Deferent duct, 13. Hemipenes (flaccid state), 14. Retractor muscle. Bar: $1 \mathrm{~cm}(\mathrm{~A})$ dan $2 \mathrm{~cm}(\mathrm{~B})$.

\section{CONCLUSION}

Male reproductive organs of the $V$. s. bivittatus were generally similar to other reptiles such as snakes and lizards, with characteristics a pair of hemipenes. Epididymis was not formed of head, body and radix segment. The deferent duct is a small, straight and short duct which connected the epididymis to cloaca.

\section{REFERENCES}

[1] Koch A, Auliya M, Schmitz A, Kuch U, Böhme W. 2007. Morphological studies on the systematics of South East Asian water monitors (Varanus salvator Complex): nominotypic populations and taxonomic overview. Mertensiella 16: 109-180.

[2] Cabral SRP, de Souza Santos LR, Franco-Belussi L, Zieri R, Zago CES, De Oliveira C. 2011. Anatomy of the male reproductive system of Phrynops geoffroanus (Testudines: Chelidae). Maringá 33: 487-492.

[3] Porto M, de Oliveira MA, Pissinatti L, Rodrigues RL, Rojas-Moscoso JA, et al., 2013. The Evolutionary Implications of Hemipenial Morphology of Rattlesnake Crotalus durissus terrificus (Laurent, 1768) (Serpentes: Viperidae: Crotalinae). PLoS ONE 8: 1-8. 